\title{
BAHAN AJAR MOBILE LEARNING 2D BERBASIS ANDROID: SEBUAH PEMBELAJARAN BERBASIS TEKNOLOGI DALAM MENGHADAPI REVOLUSI INDUSTRI 4.0
}

\author{
Sigit Vebrianto Susilo \\ Universitas Majalengka, Jln. K.H Abdul Halim No. 103 Majalengka, \\ Email: sigit.vebrianto@gmail.com \\ Tri Ferga Prasetyo \\ Universitas Majalengka, Jln. K.H Abdul Halim No. 103 Majalengka \\ Email: triferga.prasetyo@gmail.com
}

\begin{abstract}
Facing the digital era becomes a challenge for educators in relation to the competence of educators in using technology in learning. In line with this statement, as professional educators, they should have adaptive abilities, which means they are able to adapt to the development of science and technology. One of the uses of teaching materials in this study is packaged in digital form so that both students and teachers use Android-based applications that are available on smartphones. This program aims to digitize teaching materials primarily with the use of technology in learning. Today the use of smartphones has been able to be operated by children and even more clever children than adults. And lately many cases that occur both blindness and psychiatric disorders that hit children as a result of playing online games on smartphones. Another goal of this research is to direct children to be wise in using smartphones, thereby reducing students' dependence on playing online games. In this application digitally packaged Indonesian learning materials whose material is adjusted to the 2013 curriculum. Thus, the learning process runs attractively and is able to increase student enthusiasm so that it impacts on student achievement.
\end{abstract}

Keywords:

Teaching Materials, 2D Mobile Based Android Learning, Technology Based Learning, Industrial Revolution 4.0

\begin{abstract}
Abstrak
Menghadapi era digital menjadi sebuah tantangan bagi pendidik kaitannya dengan kompetensi pendidik dalam menggunakan teknologi dalam pembelajaran. Sejalan dengan pernyataan tersebut, sebagai tenaga pendidik profesional seyogyanya harus mempunyai kemampuan adaptif yang artinya adalah mampu beradaptasi dengan perkembangan ilmu pengetahuan dan teknologi. Penggunaan bahan ajar salah satunya dalam penelitian ini dikemas dalam bentuk digital sehingga baik siswa maupun guru menggunakan aplikasi berbasis android yang tersedia dalam smartphone. Program digitalisasi bahan ajar ini bertujuan utamanya adalah penggunaan teknologi dalam pembelajaran. Hari ini penggunaan smartphone telah mampu dioperasikan oleh anak dan bahkan lebih pandai anak-anak dibandingkan orang dewasa. Dan belakangan banyak kasus yang terjadi baik kebutaan maupun gangguan kejiwaan yang melanda anak-anak akibat dari memainkan game online pada smartphone. Tujuan lain dari penelitian ini adalah mengarahkan anak-anak untuk bijak dalam menggunakan smartphone sehingga mengurangi ketergantungan siswa dalam memainkan game online. Dalam aplikasi ini dikemas secara digital materi-materi pembelajaran bahasa Indonesia yang materinya disesuaikan dengan kurikulum 2013. Dengan demikian, proses pembelajaran berjalan dengan menarik dan mampu meningkatkan antusiasme siswa sehingga berdampak terhadap prestasi belajar siswa.
\end{abstract}

Kata Kunci:

Bahan Ajar, Mobile Learning 2D Berbasis Android, Pembelajaran Berbasis Teknologi, Revolusi Industri 4.0

\section{A. PENDAHULUAN}

Sejalan dengan perkembangan zaman, hari ini kebutuhan manusia mengalami perubahan yang cukup signifikan. Penggunaan teknologi hari ini sudah menjadi kebutuhan setiap hari diberbagai sendi kehidupan manusia. Salah satunya adalah kebutuhan manusia akan penggunaan teknologi dalam hal ini handphone. Kemudahan akses yang mudah menjadi tawaran yang sangat menarik sehingga merubah budaya dan paradigma masyarakat Indonesia dewasa ini. Bagi anak-anak, efek yang ditimbulkan beragam, mulai dari kecanduan bermain game online, media sosial, bahkan sampai dengan mengakses situs-situs terlarang bagi usianya. Bertemali dengan hal tersebut, maka sudah menjadi sebuah tugas utama bagi seorang guru untuk mengarahkan siswanya untuk mulai bijak dalam menggunakan teknologi 
utamanya adalah penggunaan smartphone. Dewasa ini pembelajaran di sekolah mulai disesuaikan dengan perkembangan teknologi informasi, sehingga terjadi perubahan dan pergeseran paradigma pendidikan (Hujair, 2009).

Greenstein (2012) menyatakan bahwa pada abad 21 seyogianya siswa menguasai keilmuan, memiliki keterampilan berpikir metakognitif, kritis dan kreatif, serta mampu berkomunikasi dan berkolaborasi yang efektif (Greenstein, 2012); (Trilling \& Fadel, 2009). Pada jenjang sekolah formal, pembelajaran diarahkan untuk mengembangkan 4C (Critical Thinking, Communication, Collaboration, Creativity) (Sugiyarti \& Alrahmat, 2018: 400); (Abidin, 2015), dengan demikian guru seyogyanya mampu menerapkan pembelajaran yang berorientasi terhadap pengembangan keterampilan berpikir, bekerjasama, berkomunikasi, dan memiliki kreatifitas. Sejalan dengan pernyataan di atas, pendidikan di Abad-21 perlu mempertimbangkan berbagai hal, baik kompetensi lulusan, isi/konten pendidikan, maupun proses pembelajarannya, sehingga pendidikan di Abad-21 harus memperhatikan hal-hal berikut: (1) Pemanfaatan Teknologi Pendidikan, (2) Peran Strategis Guru/Dosen dan Peserta Didik, (3) Metode Belajar Mengajar Kreatif, (4) Materi Ajar yang Kontekstual, dan (5) Struktur Kurikulum Mandiri berbasis Individu (BSNP, 2010: 46-47). Berdasarkan "21st Century Partnership Learning Framework", terdapat beberapa kompetensi dan keahlian yang harus dimiliki oleh manusia abad 21 yaitu: Kemampuan berpikir kritis dan pemecahan masalah (Critical-Thinking and Problem-Solving Skills) (Ross, 2007). Kompetensi ini sangat menunjang keterlibatan Indonesia secara kompetitif sebagai anggota AEC 2015, karenanya akan banyak perubahan yang dialami Indonesia (Rizal, 2018: 1). Pemberlakuannya menjadi momentum yang baik untuk melakukan perbaikan-perbaikan pada sektor pendidikan Indonesia agar mampu menghasilkan SDM yang memiliki daya saing tinggi. Fernandes 2012 menyatakan bahwa Kompetensi SDM yang dibutuhkan dalam menghadapi era pasar bebas ASEAN meliputi $80 \%$ soft skill (leadership, self motivation, creative thinking) dan $20 \%$ hard skill (Rizal, 2018: 1).
Dewasa ini, pembelajaran di Sekolah Dasar masih berjalan hanya menuntaskan kewajiban baik kegiatan guru maupun kegiatan siswa. Kegiatan belajar mengajar berjalan seperti biasa yang dalam pandangan penulis merupakan kegiatan mekanistis yang berjalan memiliki kesamaan dari hari ke hari. Hal ini terjadi karena pola pembelajaran tidak diawali dengan tidak memiliki orientasi dalam mengajar. Pada akhirnya, pembelajaran berjalan hanya bertujuan agar siswa mendapatkan nilai sempurna kemudian selesai tugas guru. Memasuki era teknologi yang serba digital, seyogianya pola pembelajaran di Sekolah Dasar sudah harus adaptif sehingga sesuai dengan kebutuhan siswa hari ini. Penggunaan teknologi seperti smartphone ratarata sudah mulai dikuasai oleh berbagai kalangan tidak terkecuali oleh anak-anak. Oleh sebab itu, pendidikan seyogianya mampu menjadi ujung tombak dalam mengembangka generasi penerus bangsa untuk memiliki multi kecakapan dalam multidimensional (Susilo, 2018).

Tujuan dari penelitian dan pengembangan digitalisasi bahan ajar yang dikemas ke dalam mobile learning 2D berbasis android salah satunya adalah mengemas sebuah sistem pembelajaran yang menarik dan memotivasi belajar siswa dengan menggunakan smartphone sebagai sarana media pembelajaran. Tujuan yang lebih luas lagi adalah meminimalisir siswa pemanfaatan smartphone tersebut untuk tidak hanya bermain game online dan media sosial saja, namun demikian mencoba sedikit merubah kebiasaan siswa dengan diarahkan bermain smartphone namun dalam koridor belajar.

Berbagai penelitian berkenaan dengan penggunaan atau oengembangan mobile learning telah banyak dilakukan oleh berbagai peneliti di Indonesia. Penelitian mengenai mobile learning dilakukan oleh Arif (2016) yang menyatakan bahwa hasil penelitian pengambangan model pembelajaran ICT Literacy M-Learning mampu meningkatkan hasil belajar siswa. Tidak hanya itu, produk dari M-Learning ini juga dapat meringankan beban guru dalam mengajar serta produk ini dapat dikembangkan oleh guru. Selanjutnya Sibarani, Mumu, \& Sukrawan (2019) berdasarkan hasil penelitian diperoleh bahwa produk mobile learning memiliki kategori layak digunakan dengan tingkat ketercapaian sebesar 
88,5\%. Produk mobile learning dapat diimplementasikan sebagai treatment pada kelas eksperimen. Indeks peningkatan hasil belajar diperoleh sebesar 0,73 masuk dalam kategori baik. Kesimpulan penelitian ini bahwa terdapat peningkatan hasil belajar setelah penggunaan mobile learning lebih besar dibandingkan dengan kelas yang tidak menggunakan mobile learning. Berikutnya oleh Rahmawati \& Mukminan (2017) menyatakan bahwa m-learning memenuhi kriteria dan dinyatakan layak sebagai media pembelajaran berdasarkan validasi dengan kategori "baik", keefektifan pembelajaran geografi lebih baik dengan menggunakan m-learning dibuktikan dengan adanya ketuntasan belajar pada kelas eksperimen, dan m-learning signifikan mendukung kemandirian dan hasil belajar peserta didik.

Penggunaan perangkat mobile berupa smartphone dalam konteks bahan pembelajaran ini dinamakan mobile learning. Dikkers, Martin, \& Coulter (2011: 21) menyatakan bahwa mlearning merupakan suatu proses memindahkan informasi dan kapasitas berkomunikasi yang berasal dari pusat dan diberikan kepada setiap tangan individu peserta didik. Mobile learning memiliki karakteristik yang praktis dan dapat dibawa kemanapun. Salah satu pertimbangan dalam mengembangkan smartphone menjadi bahan pembelajaran mobile learning adalah basis sistem yang digunakan. Sistem operasi merupakan penghubung antara aplikasi dengan hardware sehingga pengguna dapat melaksanakan fungsifungsi tertentu (Amirullah, Gufron \& Hardinata, 2017: 98).

Cobcroft, Rachel S and Towers, Stephen Smith, Judith and Bruns, Axel, 2006. Dalam mengikuti prinsip-prinsip desain, teknologi mobile dapat memberikan kontribusi untuk meningkatkan pengalaman belajar yang berkualitas. M-learning bisa berperan dalam meningkatkan fleksibilitas belajar menjadi kegiatan yang lebih personal dan berpusat pada peserta didik selain itu, m-learning dapat mendukung pembangunan pengetahuan sosial antara peserta didik dengan meningkatkan kritis, kreatif, kolaboratif dan komunikatif (Cobcroft et al, 2006).

Penelitian ini termasuk jenis penelitian pengembangan (R\&D) dengan model ADDIE (Analysis, Design, Development, Implementation dan Evaluating) namun dibatasi sampai tahap Implementation (Mulyatiningsih: 2012). Pada penelitian pengembangan ini hanya menilai kelayakan produk yang dikembangkan, tidak sampai menilai keefektifan dari produk mobile learning 2D berbasis Android. Tahap awal dari penelitian ini adalah melaksanakan analysis yang terdiri dari analisis kebutuhan dan karakteristik siswa, analisis materi, analisis alat pembuat bahan ajar versi cetak, digital dan analisis spesifikasi. Tahap kedua adalah desain yang terdiri dari pembuatan flowchart, pembuatan storyboard bahan ajar digital dan cetak, penyusunan soal, pembuatan desain, gambar, dan komponen pada aplikasi. Tahap ketiga adalah development yang terdiri dari pembuatan aplikasi mobile learning 2D berbasis Android, validasi bahan ajar dan revisi bahan ajar versi cetak. Tahap keempat adalah implementation merupakan tahap uji coba bahan ajar di sekolah. Selanjutnya diperoleh produk akhir berupa bahan ajar mobile learning 2D berbasis Android. Sumber data dalam penelitian ini adalah 2 orang ahli bahan ajar dan dan 2 orang ahli bahasa. Jumlah sampel yang digunakan sebanyak 130 siswa. Instrumen yang digunakan adalah angket penilaian bahan ajar untuk ahli bahan ajar, ahli materi dan siswa. Teknik pengumpulan data yang digunakan adalah observasi ke sekolah (studi penjajakan materi dan memberikan angket pengguna smartphone android) dan pemberian angket validasi ahli dan tanggapan siswa. Data kualitas bahan ajar mobile learning 2D berbasis Android ini berupa data deskriptif persentase. Setelah data terkumpul dari para ahli dan siswa kemudian dihitung persentasenya.

\section{B. HASIL DAN PEMBAHASAN}

Berdasarkan hasil pengolahan data, hasil penilaian dari kualitas bahan ajar oleh ahli materi ditinjau dari aspek materi sebesar 92,86\% dengan kategori sangat baik, ditinjau dari aspek pembelajaran sebesar $97,92 \%$ dengan kategori sangat baik, dan ditinjau dari aspek evaluasi sebesar 100\% dengan kategori sangat baik. Secara keseluruhan kualitas media pembelajaran yang dinilai oleh 2 orang ahli materi sebesar 95,83\% dengan kategori 
sangat baik.

Tabel 1. Penilaian Kelayakan Bahan Ajar oleh Ahli Bahan Ajar

\begin{tabular}{cr}
\hline Aspek & Persentase \\
Materi & $93 \%$ \\
Pembelajaran & $98 \%$ \\
Evaluasi & $100 \%$ \\
\hline
\end{tabular}

Selanjutnya berdasarkan hasil penilaian kualitas bahan ajar oleh ahli multimedia ditinjau dari aspek tulisan sebesar 87,50\% dengan kategori sangat baik, ditinjau dari aspek rekayasa perangkat lunak sebesar $89,06 \%$ dengan kategori sangat baik, ditinjau dari aspek tampilan sebesar 91,67\% dengan kategori sangat baik. Secara keseluruhan kualitas bahan ajar mobile learning 2D berbasis android yang dinilai oleh 2 orang ahli multimedia sebesar $89,71 \%$ dengan kategori sangat baik. Hasil pengolahan data dapat dilihat pada tabel dibawah ini.

Tabel 2. Penilaian Kelayakan Bahan Ajar oleh Ahli Multimedia

\begin{tabular}{cc}
\hline Aspek & Persentase \\
\hline Tulisan & $87 \%$ \\
Rekayasa Perangkat Lunak & $89 \%$ \\
Tampilan & $92 \%$ \\
\hline
\end{tabular}

Berikutnya berdasarkan hasil penilaian kualitas bahan ajar mobile learning 2D berbasis android oleh siswa ditinjau dari aspek pembelajaran sebesar $82,11 \%$ dengan kategori baik, ditinjau dari aspek tulisan sebesar $82,33 \%$ dengan kategori baik, ditinjau dari aspek materi sebesar 83,67\% dengan kategori baik, ditinjau dari aspek tampilan sebesar $87,83 \%$ dengan kategori sangat baik, dan ditinjau dari aspek rekayasa perangkat lunak sebesar $89,83 \%$ dengan kategori sangat baik. Secara keseluruhan kualitas bahan ajar mobile learning
2D berbasis android yang di uji cobakan sebesar 85,13\% dengan kategori baik. Hasil pengolahan data dapat dijabarkan sebagai berikut.

Tabel 3. Hasil Uji Coba Pertama

Kualitas Bahan Ajar menurut Tanggapan Siswa

\begin{tabular}{|c|c|}
\hline Aspek & Persentase \\
\hline Pembelajaran & $82 \%$ \\
\hline Tulisan & $82 \%$ \\
\hline Materi & $84 \%$ \\
\hline Tampilan & $88 \%$ \\
\hline $\begin{array}{c}\text { ekayasa Perangkat } \\
\text { Lunak }\end{array}$ & $89 \%$ \\
\hline
\end{tabular}

Berdasarkan hasil yang diperoleh dari uji coba diketahui persentase terendah pada setiap aspeknya adalah aspek pembelajaran $82,11 \%$ dan $84,24 \%$ dengan kategori baik. Berdasarkan hasil penelitian, siswa menyatakan bahwa di dalam aplikasi perlu ditambahkan konten yang lebih menarik seperti video pembelajaran, GIF (animasi bergerak) sehingga aplikasi menjadi lebih menarik dan dapat menarik minat siswa. Persentase tertinggi pada setiap aspeknya adalah aspek rekayasa perangkat lunak $89,83 \%$ dan 90,91\% dengan kategori sangat baik. Berdasarkan hasil penelitian, siswa menyatakan aplikasi pembelajaran mobile learning ini merupakan inovasi baru yang digunakan di dalam proses pembelajaran di kelas dan aplikasi mudah digunakan.

Sejalan dengan hasil penelitian di atas, penggunaan mobile learning berbasis android mampu meningkatkan aktivitas dan motivasi belajar siswa. Dengan menggunakan mobile learning, siswa dapat belajar kapanpun dan dimanapun tidak terpaku terhadap tempat dan waktu dimana siswa melakukan aktivitas (Arifpurnamaya, 2012); Fatmawati, 2015:15); Purbasari: 2013). Dengan menggunakan Mobile Learning juga mampu mengatasi keterbatasan alokasi waktu untuk materi tertentu serta dapat melatih siswa untuk dapat belajar secara mandiri dari sumber-sumber yang telah disediakan (Yuniati, 2011: 94). 


\section{SIMPULAN}

Berdasarkan hasil penelitian, penggunaan bahan ajar mobile learning 2D berbasis android mampu secara efektif meningkatkan motivasi dan antusiasme belajar siswa. Penggunaan smartphone sebagai sarana media pembelajaran memberikan dampak positif bagi minat belajar siswa. Para siswa memberikan respon baik terhadap penggunaan aplikasi karena memang cara penggunaannya seperti bermain game namun berisikan muatan materi pembelajaran. Namun demikian, pengembangan bahan ajar mobile learning 2D berbasis android masih perlu dikembangkan kembali dengan menambahkan unsur-unsur gambar, video, dan gambar GIF sehingga secara tampilah akan lebih menarik.

\section{DAFTAR PUSTAKA}

Abidin, Y. (2015) "Pembelajaran Multiliterasi: Sebuah Jawaban atas Tantangan Pendidikan Abad Ke-21 dalam Konteks Keindonesiaan”. Bandung: PT Refika Aditama.

Amirullah, Gufron dan Hardinata, Restu. (2017) Pengembangan Mobile Learning Bagi Pembelajaran. JKKP : Jurnal Kesejahteraan Keluarga dan Pendidikan [JKKP] Vol.04 No.02. doi.org/10.21009/JKKP.042.07. hal. 98.

Arifpurnamayana, M. I. (2012). Rancangan dan Pembuatan Mobile Learning Berbasis Android. [Online]. Diakses pada http://repository.gunadarma.ac.id.

Arif, Muhammad Budi (2016) Model pembelajaran M-Learning untuk meningkatkan hasil belajar mata pelajaran Pendidikan Agama Islam di MTs. Brawijaya Mojokerto. Jurnal TA'DIBIA Jurnal Ilmiah Pendidikan Agama Islam Vol. 6 No. 2 Nov 2016. h. 113-122.

Badan Standar Nasional Pendidikan (2010). Paradigma Pendidikan Nasional Di Abad-21. Jakarta:BSNP.

Cobcroft, Rachel $S$ and Towers, Stephen and Smith, Judith and Bruns, Axel. (2006) Mobile Learning in review: Opportunities and Challenges for learners, teachers, and institutions. In Proceedings Online Learning and Teaching (OLT) Conference 2006, pages pp.21-30, Queensland University of Technology, Brisbane.

Dikkers, S., Martin, J., \& Coulter, B. (2011). Mobile media learning: amazing uses of mobile devices for learning. Halifax: ETC Press.

Fatmawati, S. (2015). Pengembangan Mobile Learning Berbasis Android Menggunakan Adobe Flash CS6 Pada Mata Pelajaran Bahasa Inggris Untuk Meningkatkan Hasil Belajar Siswa Kelas X TKJ SMK Hidayah Semarang. Skripsi. Universitas Negeri Semarang.

Greenstein, L. (2012) Assessing 21st Century Skills: a guide to evaluating mastery and authentic learning. London: Sage Publications Ltd.

Lina Sugiyarti, Alrahmat Arif, Mursalin. (2018) Pembelajaran Abad 21 Di SD. Prosiding Seminar dan Diskusi Nasional Pendidikan Dasar 2018 Prosiding Seminar dan Diskusi Nasional Pendidikan Dasar 2018. Hal 400.

Hujair AH. Sanaky. (2009) Media Pembelajaran. Yogyakarta: Safiria Insania Press.

Mulyatiningsih, Endang. (2012) Metode Penelitian Terapan Bidang Pendidikan. Alfabeta : Bandung.

Rahmawati, E Mardliyani, Mukminan (2017) Pengembangang M-Learning Untuk Mendukung Kemandirian Dan Hasil Belajar Mata Pelajaran Geografi. Jurnal Inovasi Teknologi Pendidikan Volume 4, No 2 October 2017 (157-166) Online: http://journal.uny.ac.id/index.php/jitp

Rizal (2018) Mengajar Cara Berpikir, Meraih Keterampilan Abad 21. Seminar Nasional Pendidikan PGSD UMS \& HDPGSDI Wilayah Jawa. Hal 1.

Ross, David. (2007) Framework for 21st century learning. Diakses tanggal 01 Mei 2017 dari http://www.p21.org/our-work/p21framework.

Sibarani Hendra P. , Komaro M, Sukrawan Y (2019) Implementasi Mobile Learning Berbasis Aplikasi Smartphone Untuk Meningkatkan Hasil Belajar Siswa Pada 
Mata Pelajaran Teknik Pemesinan Bubut. Journal of Mechanical Engineering Education, Vol. 6, No. 1, Juni 2019. https://ejournal.upi.edu/index.php/jmee/a rticle/view/18240/9912

Susilo, S. V. (2018). Refleksi Nilai-Nilai Pendidikan Ki Hadjar Dewantara Dalam Upaya Upaya Mengembalikan Jati Diri Pendidikan Indonesia. Cakrawala Pendas, 4(1), 33-41. https://doi.org/http://dx.doi.org/10.31949/ jcp.v4i1.710

Trilling, B dan Fadel, C. (2009) " $21^{\text {st }}$ Century Skills Learning For Life In Our Times". USA: HB Printing.
Purbasari, Rohmi Julia. (2013). Pengembangan Aplikasi Android sebagai Media Pembelajaran Matematika pada Materi Dimensi Tiga untuk Siswa SMA Kelas $\mathrm{X}$. Jurnal Online Universitas Negeri Malang Vol. 1. No. 4. (Online). Tersedia di http: jurnalonline.um.ac.id/data/artikel.

Yuniati, Lukita. (2011) Pengembangan Media Pembelajaran Mobile Learning Efek Doppler Sebagai Alat Bantu Dalam Pembelajaran Fisika Yang Menyenangkan. JP2F. Vol. 2. No. 2. (Online). 